\title{
PENERAPAN GOOD CORPORATE GOVERNANCE, WHISTLEBLOWING SYSTEM DAN RISIKO SANKSI PAJAK TERHADAP KEPATUHAN WAJIB PAJAK DI KABUPATEN SLEMAN

\author{
Syska Lady Sulistyowatie ${ }^{1}$
} \\ syskaladys@unwidha.ac.id
}

Reza Widhar Pahlevi

rezawp@uii.ac.id

Fakultas Ekonomi dan Bisnis

Universitas Widya Dharma ${ }^{1}$

Universitas Islam Indonesia ${ }^{2}$

\begin{abstract}
Tax compliance still needs to be improved by encouraging the implementation of transparent taxation, namely the transparency of tax management in all areas, both administrative and management of the use of funds derived from tax revenue. The real effort that must be done to implement the transparency is through the bureaucracy reform movement in the service system and tax administration that is through the implementation and implementation of Good Governance.

Good governance is a well-executed organizational governance, by carrying out the principles of openness, justice and accountability in order to achieve the goals of the organization. The problems that will be studied by the researcher is a social and dynamic problem. Therefore, the researcher chooses to use quantitative research method to determine how to find, collect, process and analyze the data of the research result, so that this research is expected to give input for the need of strengthening of harmony between Good Corporate Governance and Whistleblowing System and the need to create system or policies and operational procedures of taxation sanction risk required for tax compliance implementation. The results showed that there is influence between the implementation of Good Corporate Governance to tax compliance, there is influence between Whistleblowing System on tax compliance, there is influence between Taxation Sanction on tax compliance.
\end{abstract}

Key Word: Good Corporate Governance, Whistleblowing System, Taxation Sanctions and Tax Compliance.

\section{PENDAHULUAN}

Dewasa ini pajak merupakan pendapatan terbesar pada suatu negara yang digunakan untuk biaya operasional pemerintahan. Tetapi dalam menghimpun pajak dari masyarakat tidaklah mudah, karena timbal balik yang diterima oleh masyarakat atau wajib pajak tidak diperoleh secara langsung sehingga wajib pajak tidak merasa mendapat apapun dari pembayaran pajak yang telah dilakukan. Hal inilah yang menyebabkan para wajib pajak melakukan penghindaran pajak, bahkan seringkali terjadi perlawanan pajak. Agar tujuan penerimaan pajak dapat tercapai dengan baik maka perlu ada proses penegakan hukum di bidang perpajakan apalagi dalam menegakkan self assessment system, karena hal tersebut sesuai dengan isi dari pengertian pajak sebagai iuran wajib yang dipaksakan sesuai dengan undang-undang, penegakan hukum berarti memberikan segala sanksi yang tepat dan adil atas pelanggaran yang dilakukan dalam pelaksanaan perpajakan.
Dalam rangka mencegah dan melakukan deteksi dini atas pelanggaran yang mungkin terjadi di lingkungan Direktorat Jenderal Pajak (DJP) melalui peningkatan peran serta pegawai dan masyarakat secara aktif untuk menjadi pelapor pelanggaran (Whistleblower), DJP telah menerbitkan Peraturan Direktur Jenderal Pajak Nomor PER-22/PJ/2011 tanggal 19 Agustus 2011 tentang Kewajiban Melaporkan Pelanggaran dan Penanganan Pelaporan Pelanggaran (Whistleblowing) di Lingkungan Direktorat Jenderal Pajak (Perdirjen Nomor PER22/PJ/2011). Pemahaman mengenai Whistleblowing System Direktorat Jenderal Pajak diharapkan dapat mencegah dan mengurangi pelanggaran yang terjadi, membentuk budaya baru DJP yang korektif, serta meningkatkan kepatuhan pegawai DJP. Hal ini pada akhirnya diharapkan akan mendukung pencapaian sasaran penerimaan pajak yang optimal. Keputusan wajib pajak untuk menjadi patuh atau tidak patuh terhadap kewajiban perpajakannya merupakan 
tanggapan atas kondisi faktor internal dan eksternal dari wajib pajak.

Kepatuhan wajib pajak masih perlu ditingkatkan dengan mendorong pelaksanaan perpajakan yang transparan, yaitu transparansi pengelolaan pajak di segala bidang, baik bidang administrasi maupun pengelolaan penggunaan dana yang bersumber dari pendapatan pajak tersebut. Upaya nyata yang harus dilakukan untuk melaksankan transparansi tersebut adalah melalui gerakan reformasi birokrasi dalam sistem pelayanan dan administrasi perpajakan yaitu melalui penerapan dan pelaksanaan Good Corporate Governance. Good governance merupakan tata kelola organisasi yang dilaksanakan dengan baik, dengan menjalankan prisip-prinsip keterbukaan, keadilan dan dapat dipertanggungjawabkan dalam rangka mencapai tujuan dari organisasi (Lukviarman, 2016).

\section{KAJIAN PUSTAKA DAN PENGEMBANGAN HIPOTESIS}

\section{a. Pengaruh antara penerapan Good Corporate Governance terhadap Kepatuhan Wajib Pajak}

Kepatuhan pajak menurut Rustiyaningsih (2011) diartikan sebagai suatu keadaan yang mana wajib pajak patuh dan mempunyai kesadaran dalam memenuhi kewajiban perpajakan. Pada prinsipnya kepatuhan perpajakan adalah wajib pajak yang taat dan memenuhi serta melaksanakan kewajiban perpajakan sesuai dengan ketentuan peraturan perundangundangan perpajakan (Sasmita, 2013). Reformasi birokrasi perpajakan merupakan reformasi menyeluruh dengan menerapkan dan melaksanakan Good Governance. Peraturan pemerintah No. 101 Tahun 2000, merumuskan good governance yaitu: "Kepemerintahan yang mengembangkan dan menerapkan prinsip-prinsip profesionalitas, akuntanbilitas, transparansi, pelayanan prima, demokrasi, efesiensi, efektivitas, supremasi hukum dan dapat diterima oleh seluruh masyarakat".

Rahman (2009), dalam hasil penelitiannya yang menggunakan indikator good governance mengatakan bahwa good governance mempunyai pengaruh positif yang signifikan terhadap kepatuhan wajib pajak. Alijoyo dan Subartono (2014), menyebutkan Governance pada dasarnya berbicara tentang dua aspek yakni, governance structure dan governance process atau governance mechanism pada sebuah perusahaan. Governance structure adalah struktur hubungan pertanggung jawaban dan pembagian peran di antara berbagai organ utama perusahaan, yakni pemilik/pemegang saham, pengawas/ komisaris, dan pengelola/manajemen. Sedangkan governance process adalah mekanisme kerja dan interaksi aktual di antara organ-organ tersebut. Kepatuhan wajib pajak masih perlu ditingkatkan dengan mendorong pelaksanaan perpajakan yang transparan, yaitu transparansi pengelolaan pajak di segala bidang, baik bidang administrasi maupun pengelolaan penggunaan dana yang bersumber dari pendapatan pajak tersebut (Siringoringo, 2015).

Upaya nyata yang harus dilakukan untuk melaksankan transparansi tersebut adalah melalui gerakan reformasi birokrasi dalam sistem pelayanan dan administrasi perpajakan yaitu melalui penerapan dan pelaksanaan Good Governance. Good governance merupakan tata kelola organisasi yang dilaksanakan dengan baik, dengan menjalankan prisip-prinsip keterbukaan, keadilan dan dapat dipertanggungjawabkan dalam rangka mencapai tujuan dari organisasi (Lukviarman, 2016).

$\mathrm{H}_{1}$ : Terdapat pengaruh antara penerapan Good Corporate Governance terhadap Kepatuhan Wajib Pajak

\section{b. Pengaruh antara penerapan Whistleblowing System terhadap Kepatuhan Wajib Pajak}

Selain penerapan dan pelaksanaan Good Governance, juga perlu menerapkan system pengawasan yang lebih baik, yaitu dengan penerapan Whistle Blowing System yang mulai diterapkan pada tahun 2012 dengan dikeluarkannya Surat Edaran Direktur Jendral Pajak Nomor SE-11/PJ/2011. Whistle Blowing system (WiSe) adalah sebuah aplikasi yang disediakan oleh kementerian keuangan bagi setiap orang yang memiliki informasi tentang adanya pelanggaran atau penyelewangan dan tindak kejahatan korupsi yang dilakukan oleh SDM yang ada dilingkungan Kementerian Keuangan Republik Indonesia. Pengadaan aplikasi ini menjadi sebuah bukti nyata yang ingin ditunjukkan oleh DJP kepada wajib pajak, bahwa DJP kini serius menghadapi dan memberantas korupsi maupun penyelewengan- 
penyelewengan yang ingin dilakukan oleh aparatur DJP, yang pada akhirnya diharapkan akan mampu mengembalikan kepercayaan masyarakat sehingga akan dapat menciptakan dan meningkatkan kepatuhan wajib pajak.

Penerapan Whistle Blowing System menjadi suatu alat yang dapat dipergunakan untuk mencegah kebocoran-kebocoran pajak dalam rangka mencegah dan melakukan deteksi dini atas pelanggaran yang mungkin terjadi di lingkungan Direktorat Jenderal Pajak (DJP) melalui peningkatan peran serta pegawai dan masyarakat secara aktif untuk menjadi pelapor pelanggaran (Whistleblower), DJP telah menerbitkan Peraturan Direktur Jenderal Pajak Nomor PER22/PJ/2011 tanggal 19 Agustus 2011 tentang Kewajiban Melaporkan Pelanggaran dan Penanganan Pelaporan Pelanggaran (Whistle Blowing) di Lingkungan Direktorat Jenderal Pajak (Perdirjen Nomor PER-22/PJ/2011), Whistle Blowing System DJP juga dimaksudkan untuk membangun kembali public trust terhadap DJP dan mengajak seluruh pegawai DJP untuk mengubah budaya permisif menjadi budaya korektif yang berarti tidak akan pernah mentolerir adanya pelanggaran dengan cara melaporkannya ke saluran pengaduan yang telah disediakan.

$\mathrm{H}_{2}$ : Terdapat pengaruh antara Whistleblowing System terhadap Kepatuhan Wajib Pajak

\section{c. Pengaruh antara Risiko Sanksi Pajak terhadap Kepatuhan Wajib Pajak}

Risiko sanksi pajak merupakan suatu sanksi yang akan diterima apabila wajib pajak tidak patuh terhadap pelaksanaan kewajiban perpajakannya, namun sebaliknya sanksi tersebut tidak akan diterima apabila wajib pajak tersebut melaksanakan kewajiban perpajakannya sesuai dengan peraturan perpajakan yang berlaku (Siringoringo, 2015). Penerapan risiko sanksi pajak dalam system administrasi perpajakan melalui sanksi administrasi dilakukan agar tujuan penghimpunan dana dari masyarakat dapat tetap terlaksana, dimana sanksi administrasi tidak akan menghilangkan atau menghapus kewajiban perpajakan yang melekat pada wajib pajak yang dikenakan sanksi tersebut. Menurut Mardiasmo (2016), sanksi perpajakan merupakan alat pencegah (preventif) agar wajib pajak tidak melanggar norma pepajakan.
Pelaksanaan sanksi pajak dapat menyebabkan terpenuhinya kewajiban perpajakan oleh wajib pajak, sehingga wajib pajak akan patuh karena mereka memikirkan adanya sanksi berat berupa denda akibat tindakan ilegal dalam usahanya menyelundupkan pajak (Pujiwidodo, 2016). Kepatuhan wajib pajak masih perlu ditingkatkan dengan mendorong pelaksanaan perpajakan yang transparan, yaitu transparansi pengelolaan pajak di segala bidang, baik bidang administrasi maupun pengelolaan penggunaan dana yang bersumber dari pendapatan pajak tersebut (Siringoringo, 2015). Agar tujuan penerimaan pajak dapat tercapai dengan baik maka perlu ada proses penegakan hukum di bidang perpajakan apalagi dalam menegakkan self assessment system, karena hal tersebut sesuai dengan isi dari pengertian pajak sebagai iuran wajib yang dipaksakan sesuai dengan undang-undang, penegakan hukum berarti memberikan segala sanksi yang tepat dan adil atas pelanggaran yang dilakukan dalam pelaksanaan perpajakan.

$\mathrm{H}_{3}$ : Terdapat pengaruh antara Risiko Sanksi Pajak terhadap Kepatuhan Wajib Pajak

\section{METODE PENELITIAN}

\subsection{Jenis Penelitian}

Jenis penelitian yang dilakukan adalah penelitian kuantitatif kausalitas karena penelitian ini adalah untuk menguji hipotesis yang telah diajukan yaitu menguji pengaruh variabel-variabel independen terhadap variabel dependen.

\subsection{Lokasi Penelitian}

Penelitian ini dilaksanakan di Kabupaten Sleman, Daerah Istimewa Yogyakarta.

\subsection{Definisi Operasional dan Pengukuran Variabel}

\section{Good Corporate Govenance (GCG)}

Good Corporate Governance (GCG) adalah hubungan antara manajemen atas perusahaan yaitu yang terdiri dari $\mathrm{BoD}$, manajer senior, dan pemangku kepentingan yang mana merupakan mekanisme yang memberikan wewenang untuk mengendalikan perusahaan berdasarkan keputusan yang diambil oleh manajemen atas (Tricker, 2004). Indikator pengukuran prosedur implementasi Good Corporate Governance 
(GCG) adalah (1) Integrity and impartiality - bekerja secara tuntas, ber etika dan sesuai kepentingan Instansi. (2) Promoting the public good-menggunakan setiap peluang untuk meningkatkan nilai asset public dan institusi serta menjamin produktifitas dari penggunaan sumberdaya yang ada untuk mencapai tujuan organisasi. (3) Commitment to the system of government -tanggap terhadap kebutuhan pemerintah dan mengimplementasikan kebijakan dan keputusan secara keseluruhan dan professional. Accountability and transparency -bertanggung jawab pada setiap keputusan yang diambil dan menyediakan mekanisme yang sesuai dalam rangka pemahaman standar -standar yang dipergunakan serta memiliki prosedur yang jelas, peran atau posisi dan tangggung yang jelas dalam pengambilan keputusan dan pelaksanaan otoritas. (5) Public defensibility menjamin instansi berkomitmen untuk mencapai kebutuhan dan keinginan public dan memiliki mekanisme yang dibutuhkan untuk memastikan komitmen tersebut dapat dipertahankan.

\section{Whistleblowing}

Menurut Sisingoringo (2015), Whistleblowing didefinisikan sebagai sutu tindakan melaporkan pelanggaran dalam suatu organisasi kepada pihak lain baik di dalam maupun di luar organisasi. Indikator Whistleblowing dalam penelitian ini adalah : (a) Mencegah Pelaku Melakukan Pelanggaran (Asas Prevention). (b) Mendorong antusiasme whistleblower (Asas Early Detection). (c) Penanganan yang efektif (Asas Proper Investigation).

\section{Risiko sanksi pajak}

Risiko sanksi pajak merupakan suatu sanksi yang akan diterima apabila wajib pajak tidak patuh terhadap pelaksanaan kewajiban perpajakannya, namun sebaliknya sanksi tersebut tidak akan diterima apabila wajib pajak tersebut melaksanakan kewajiban perpajakannya sesuai dengan peraturan perpajakan yang berlaku (Siringoringo, 2015). Penerapan risiko sanksi pajak dalam system administrasi perpajakan melalui sanksi administrasi dilakukan agar tujuan penghimpunan dana dari masyarakat dapat tetap terlaksana, dimana sanksi administrasi tidak akan menghilangkan atau menghapus kewajiban perpajakan yang melekat pada wajib pajak yang dikenakan sanksi tersebut.

\section{Kepatuhan Wajib Pajak}

Kepatuhan perpajakan menurut Rustiyaningsih (2011) diartikan sebagai suatu keadaan yang mana wajib pajak patuh dan mempunyai kesadaran dalam memenuhi kewajiban perpajakan. Indikator yang digunakan untuk mengukur kepatuhan wajib pajak (Carolina dkk, 2011), yakni: (a) Benar dalam perhitungan pajak terhutang. (b) Benar dalam pengisian SPT. (c) Tepat waktu dalam melaporkan SPT. (d) Melakukan kewajiban dengan secara sukarela (atas kesadaran sendiri) sesuai dengan aturan perpajakan.

\subsection{Populasi dan Sampel}

Populasi yang digunakan dalam penelitian adalah wajib pajak orang pribadi yang memiliki NPWP (Nomor Pokok Wajib Pajak) yang terdaftar di Kabupaten Sleman. Karena jumlah wajib pajak yang terdaftar di Kabupaten Sleman sangat besar, maka perlu dibuat sampling, dimana dari jumlah wajib pajak orang pribadi yang terdaftar di Kabupaten Sleman akan diambil sampel dengan mengunakan teknik pengambilan sampel yaitu non probability sampling, dimana pengambilan sampel tidak memperhitungkan semua anggota populasi mempunyai kesempatan yang sama untuk dipilih secara acak sebagai sampel, dan metode yang digunakan adalah convenience sampling (Ghozali, 2013). Metode ini sangat cocok digunakan dalam penelitian ini, dikarenakan jumlah wajib pajak pribadi yang begitu besar di wilayah Kabupaten Sleman. Oleh karena itu ada beberapa penulis menggunakan istilah accidental sampling - tidak disengaja - atau juga captive sample (man-on-thestreet). Peneliti akan merujuk pada pendapat Santoso (2004), yang menyatakan bahwa dengan jumlah variabel laten (konstruk) sampai dengan lima buah, dan setiap konstruk dijelaskan oleh tiga atau lebih indikator, jumlah sampel 100 - 150 sudah dianggap memadai. Hal ini sesuai dengan Ghozali (2008) menyatakan bahwa pengambilam sampel dalam analisis data, membutuhkan sampel sebanyak 5 kali dari banyaknya parameter yang akan diduga. Penelitian ini menggunakan 44 indikator untuk seluruh variabel, sehingga banyaknya sampel yang memenuhi persyaratan SEM adalah $44 \times 5=220$ responden yaitu wajib pajak yang terdaftar di Kabupaten Sleman. 


\subsection{Teknik Analisis Data}

Untuk mengetahui apakah ada pengaruh yang signifikan dari beberapa variabel independen terhadap variabel dependen maka digunakan model regresi linier berganda yang dirumuskan sebagai berikut:

Kepatuhan $=\alpha+\beta_{1} \mathrm{CG}+\beta_{2} \mathrm{WBS}+\beta_{3}$ SANKSI $+\mathrm{e}$ Keterangan :

$\begin{array}{ll}\alpha & =\text { Konstanta } \\ \beta 1-\beta 3 & =\text { Koefisien regresi } \\ \text { Kepatuhan } & =\text { Kepatuhan Wajib Pajak } \\ \text { CG } & =\text { Corporate Governance } \\ \text { WBS } & =\text { Whistleblowing System } \\ \text { SANKSI } & =\text { Sanksi Pajak } \\ \mathrm{e} & =\text { Nilai Error }\end{array}$

\section{HASIL DAN PEMBAHASAN}

Dari hasil uji validitas dan reliabilitas diperoleh hasil sebagai berikut :

Tabel 1.

Uji Validitas dan Reliabilitas

\begin{tabular}{|c|c|c|c|c|c|}
\hline $\begin{array}{c}\text { Variabe } \\
1\end{array}$ & $\begin{array}{c}\text { Indikat } \\
\text { or }\end{array}$ & $\begin{array}{c}\text { Pearso } \\
n \\
\text { Correla } \\
\text { tion }\end{array}$ & $\begin{array}{c}\text { Sig } \\
\text { nifi } \\
\text { kan } \\
\text { si }\end{array}$ & $\begin{array}{c}\text { Ketera } \\
\text { ngan }\end{array}$ & $\begin{array}{l}\text { Cronb } \\
\text { ach's } \\
\text { Alpha }\end{array}$ \\
\hline \multirow{10}{*}{$\begin{array}{c}\text { GOOD } \\
\text { CORP } \\
\text { ORAT } \\
E \\
\text { GOVE } \\
\text { RNAN } \\
\text { CE }\end{array}$} & Item 1 & 0,757 & 0,00 & Valid & \multirow{10}{*}{0,920} \\
\hline & Item 2 & 0,925 & $\begin{array}{c}0,00 \\
0\end{array}$ & Valid & \\
\hline & Item 3 & 0,775 & $\begin{array}{c}0,00 \\
0\end{array}$ & Valid & \\
\hline & Item 4 & 0,757 & $\begin{array}{c}0,00 \\
0\end{array}$ & Valid & \\
\hline & Item 5 & 0,775 & $\begin{array}{c}0,00 \\
0\end{array}$ & Valid & \\
\hline & Item 6 & 0,775 & $\begin{array}{c}0,00 \\
0\end{array}$ & Valid & \\
\hline & Item 7 & 0,467 & $\begin{array}{c}0,00 \\
9\end{array}$ & Valid & \\
\hline & Item 8 & 0,798 & $\begin{array}{c}0,00 \\
0\end{array}$ & Valid & \\
\hline & Item 9 & 0,925 & $\begin{array}{c}0,00 \\
0\end{array}$ & Valid & \\
\hline & Item 10 & 0,824 & $\begin{array}{c}0,00 \\
0\end{array}$ & Valid & \\
\hline \multirow{2}{*}{$\begin{array}{l}\text { WHIS } \\
\text { TLEBL } \\
\text { OWIN } \\
G\end{array}$} & Item 1 & 0,460 & $\begin{array}{c}0,01 \\
1 \\
\end{array}$ & Valid & \\
\hline & Item 2 & 0,870 & $\begin{array}{c}0,00 \\
0\end{array}$ & Valid & \\
\hline
\end{tabular}

\begin{tabular}{|c|c|c|c|c|c|}
\hline \multirow[t]{8}{*}{$\begin{array}{l}\text { SYSTE } \\
M\end{array}$} & Item 3 & 0,953 & $\begin{array}{c}0,00 \\
0\end{array}$ & Valid & \multirow[t]{8}{*}{0,829} \\
\hline & Item 4 & 0,561 & $\begin{array}{c}0,00 \\
1\end{array}$ & Valid & \\
\hline & Item 5 & 0,470 & $\begin{array}{c}0,00 \\
9\end{array}$ & Valid & \\
\hline & Item 6 & 0,460 & $\begin{array}{c}0,01 \\
1\end{array}$ & Valid & \\
\hline & Item 7 & 0,746 & $\begin{array}{c}0,00 \\
0\end{array}$ & Valid & \\
\hline & Item 8 & 0,396 & $\begin{array}{c}0,03 \\
0\end{array}$ & Valid & \\
\hline & Item 9 & 0,423 & $\begin{array}{c}0,02 \\
0\end{array}$ & Valid & \\
\hline & Item 10 & 0,953 & $\begin{array}{c}0,00 \\
0\end{array}$ & Valid & \\
\hline \multirow{12}{*}{$\begin{array}{l}\text { RISIK } \\
\text { O } \\
\text { SANK } \\
\text { SI } \\
\text { PAJA } \\
\text { K }\end{array}$} & Item 1 & 0,958 & $\begin{array}{c}0,00 \\
0\end{array}$ & Valid & \multirow{12}{*}{0,943} \\
\hline & Item 2 & 0,962 & $\begin{array}{c}0,00 \\
0\end{array}$ & Valid & \\
\hline & Item 3 & 0,682 & $\begin{array}{c}0,00 \\
0\end{array}$ & Valid & \\
\hline & Item 4 & 0,453 & $\begin{array}{c}0,01 \\
2\end{array}$ & Valid & \\
\hline & Item 5 & 0,802 & $\begin{array}{c}0,00 \\
0\end{array}$ & Valid & \\
\hline & Item 6 & 0,691 & $\begin{array}{c}0,00 \\
0\end{array}$ & Valid & \\
\hline & Item 7 & 0,903 & $\begin{array}{c}0,00 \\
0\end{array}$ & Valid & \\
\hline & Item 8 & 0,958 & $\begin{array}{c}0,00 \\
0\end{array}$ & Valid & \\
\hline & Item 9 & 0,453 & $\begin{array}{c}0,01 \\
2\end{array}$ & Valid & \\
\hline & Item 10 & 0,440 & $\begin{array}{c}0,01 \\
6\end{array}$ & Valid & \\
\hline & Item 11 & 0,903 & $\begin{array}{c}0,00 \\
0 \\
\end{array}$ & Valid & \\
\hline & Item 12 & 0,707 & $\begin{array}{c}0,00 \\
0\end{array}$ & Valid & \\
\hline \multirow{8}{*}{$\begin{array}{l}\text { KEPA } \\
\text { TUHA } \\
\mathbf{N} \\
\text { WAJI } \\
\text { B } \\
\text { PAJA } \\
\text { K }\end{array}$} & Item 1 & 0,451 & $\begin{array}{c}0,01 \\
2\end{array}$ & Valid & \multirow{8}{*}{0,860} \\
\hline & Item 2 & 0,622 & $\begin{array}{c}0,00 \\
0\end{array}$ & Valid & \\
\hline & Item 3 & 0,782 & $\begin{array}{c}0,00 \\
0\end{array}$ & Valid & \\
\hline & Item 4 & 0,466 & $\begin{array}{c}0,00 \\
9\end{array}$ & Valid & \\
\hline & Item 5 & 0,908 & $\begin{array}{c}0,00 \\
0\end{array}$ & Valid & \\
\hline & Item 6 & 0,441 & $\begin{array}{c}0,01 \\
5\end{array}$ & Valid & \\
\hline & Item 7 & 0,580 & $\begin{array}{c}0,00 \\
1 \\
\end{array}$ & Valid & \\
\hline & Item 8 & 0,934 & 0,00 & Valid & \\
\hline
\end{tabular}




\begin{tabular}{l|c|c|c|c|c|}
\hline & & & 0 & \\
\cline { 2 - 5 } & Item 9 & 0,931 & $\begin{array}{c}0,00 \\
0\end{array}$ & Valid & \\
\cline { 2 - 5 } & Item 10 & 0,577 & $\begin{array}{c}0,00 \\
1\end{array}$ & Valid & \\
\cline { 2 - 5 } & Item 11 & 0,782 & $\begin{array}{c}0,00 \\
0\end{array}$ & Valid & \\
\cline { 2 - 4 } & Item 12 & 0,479 & $\begin{array}{c}0,00 \\
7\end{array}$ & Valid & \\
\hline
\end{tabular}

Sumber : Data diolah, 2018

Berdasarkan tabel diatas, diperoleh nilai $r_{\text {hitung }}$ dari semua item kuesioner meliputi variabel penelitian yaitu good corporate governance, whistleblowing system, risiko sanksi pajak, dan kepatuhan wajib pajak menunjukkan nilai angka probabilitas (sig) $<0.05$. Sehingga kuesioner dari variabel-variabel yaitu good corporate governance, whistleblowing system, risiko sanksi pajak, dan kepatuhan wajib pajak valid, serta diperoleh nilai nilai Alpha Cronbach dari semua hasil meliputi variabel penelitian menunjukkan lebih besar dari nilai 0,6. Dengan demikian jawaban-jawaban responden dari variabel-variabel penelitian yaitu good corporate governance, whistleblowing system, risiko sanksi pajak, dan kepatuhan wajib pajak, sehingga kuesioner dari variabel-variabel tersebut reliabel dan dapat digunakan untuk penelitian selanjutnya.

Untuk menguji hipotesis dalam penelitian ini digunakan model regresi linier berganda. Analisis regresi linier berganda di gunakan untuk memperoleh gambaran yang menyeluruh mengenai pengaruh antara good corporate governance, whistleblowing system, dan risiko sanksi pajak terhadap kepatuhan wajib pajak. Hasil perhitungan regresi linier berganda disajikan pada Tabel berikut :

Tabel 2.

Regresi Linear Berganda

\begin{tabular}{c|c|c|c}
\hline Variabel & $\begin{array}{c}\text { Koef. } \\
\text { Reg }\end{array}$ & $\mathbf{t}$ & Sig \\
\hline (Constant) & \multicolumn{3}{|c}{, 946} \\
\hline GCG &, 242 & 3,298 &, 001 \\
\hline Whistleblowing &, 306 & 7,698 &, 000 \\
\hline Risiko sanksi pajak &, 292 & 6,018 &, 000 \\
\hline F & \multicolumn{3}{|c}{168,851} \\
\hline Sig &, 000 \\
\hline Adj $R$ Square & \multicolumn{3}{|c}{}
\end{tabular}

Sumber : Data diolah, 2018

\section{Pengaruh antara penerapan Good Corporate Governance terhadap Kepatuhan Wajib Pajak}

Berdasarkan hasil uji t untuk good corporate governance memperoleh $p$ value sebesar 0,001 , oleh karena itu nilai sig $\mathrm{t}(0,001)<0,05$ yang berarti hipotesis diterima. Jadi, dapat disimpulkan bahwa terdapat pengaruh antara penerapan Good Corporate Governance terhadap Kepatuhan Wajib Pajak. Kepatuhan perpajakan menurut Rustiyaningsih (2011) diartikan sebagai suatu keadaan yang mana wajib pajak patuh dan mempunyai kesadaran dalam memenuhi kewajiban perpajakan. Pada prinsipnya kepatuhan perpajakan adalah wajib pajak yang taat dan memenuhi serta melaksanakan kewajiban perpajakan sesuai dengan ketentuan peraturan perundangundangan perpajakan (Sasmita, 2013).

Reformasi birokrasi perpajakan merupakan reformasi menyeluruh dengan menerapkan dan melaksanakan Good Governance. Peraturan pemerintah No. 101 Tahun 2000, merumuskan good governance yaitu : "Kepemerintahan yang mengembangkan dan menerapkan prinsip-prinsip profesionalitas, akuntanbilitas, transparansi, pelayanan prima, demokrasi, efesiensi, efektivitas, supremasi hukum dan dapat diterima oleh seluruh masyarakat".

Rahman (2009), dalam hasil penelitiannya yang menggunakan indikator good governance mengatakan bahwa good governance mempunyai pengaruh positif yang signifikan terhadap kepatuhan wajib pajak. Alijoyo dan Subartono (2014), menyebutkan Governance pada dasarnya berbicara tentang dua aspek yakni, governance structure dan governance process atau governance mechanism pada sebuah perusahaan. Governance structure adalah struktur hubungan pertanggungjawaban dan pembagian peran di antara berbagai organ utama perusahaan, yakni pemilik atau pemegang saham, pengawas atau komisaris, dan pengelola atau manajemen. Sedangkan governance process adalah mekanisme kerja dan interaksi aktual di antara organ-organ tersebut.

\section{Pengaruh antara Whistleblowing System terhadap Kepatuhan Wajib Pajak}

Berdasarkan hasil uji t untuk Whistleblowing System memperoleh $p$ value sebesar 0,000, oleh karena itu nilai sig $\mathrm{t}(0,000)<0,05$ yang berarti hipotesis 
diterima. Jadi, dapat disimpulkan bahwa terdapat pengaruh antara penerapan Whistleblowing System terhadap kepatuhan wajib pajak. Whistle Blowing System (WiSe) adalah sebuah aplikasi yang disediakan oleh kementerian keuangan bagi setiap orang yang memiliki informasi tentang adanya pelanggaran atau penyelewangan dan tindak kejahatan korupsi yang dilakukan oleh SDM yang ada dilingkungan Kementerian Keuangan Republik Indonesia.

Pengadaan aplikasi ini menjadi sebuah bukti nyata yang ingin ditunjukkan oleh DJP kepada wajib pajak, bahwa DJP kini serius menghadapi dan memberantas korupsi maupun penyelewenganpenyelewengan yang ingin dilakukan oleh aparatur DJP, yang pada akhirnya diharapkan akan mampu mengembalikan kepercayaan masyarakat sehingga akan dapat menciptakan dan meningkatkan kepatuhan wajib pajak.

Penerapan Whistle Blowing System menjadi suatu alat yang dapat dipergunakan untuk mencegah kebocoran-kebocoran pajak dalam rangka mencegah dan melakukan deteksi dini atas pelanggaran yang mungkin terjadi di lingkungan Direktorat Jenderal Pajak (DJP) melalui peningkatan peran serta pegawai dan masyarakat secara aktif untuk menjadi pelapor pelanggaran (Whistleblower), DJP telah menerbitkan Peraturan Direktur Jenderal Pajak Nomor PER22/PJ/2011 tanggal 19 Agustus 2011 tentang Kewajiban Melaporkan Pelanggaran dan Penanganan Pelaporan Pelanggaran (Whistle Blowing) di Lingkungan Direktorat Jenderal Pajak (Perdirjen Nomor PER-22/PJ/2011), Whistle Blowing System DJP juga dimaksudkan untuk membangun kembali public trust terhadap DJP dan mengajak seluruh pegawai DJP untuk mengubah budaya permisif menjadi budaya korektif yang berarti tidak akan pernah mentolerir adanya pelanggaran dengan cara melaporkannya ke saluran pengaduan yang telah disediakan.

\section{Pengaruh antara Risiko Sanksi Pajak terhadap Kepatuhan Wajib Pajak}

Berdasarkan hasil uji t untuk Risiko Sanksi Pajak terhadap Kepatuhan Wajib Pajak memperoleh $p$ value sebesar 0,000 , oleh karena itu nilai sig t $(0,000)<0,05$ yang berarti hipotesis diterima. Jadi, dapat disimpulkan bahwa terdapat pengaruh antara Risiko
Sanksi Pajak terhadap Kepatuhan Wajib Pajak. Risiko sanksi pajak merupakan suatu sanksi yang akan diterima apabila wajib pajak tidak patuh terhadap pelaksanaan kewajiban perpajakannya, namun sebaliknya sanksi tersebut tidak akan diterima apabila wajib pajak tersebut melaksanakan kewajiban perpajakannya sesuai dengan peraturan perpajakan yang berlaku (Siringoringo, 2015).

Penerapan risiko sanksi pajak dalam system administrasi perpajakan melalui sanksi administrasi dilakukan agar tujuan penghimpunan dana dari masyarakat dapat tetap terlaksana, dimana sanksi administrasi tidak akan menghilangkan atau menghapus kewajiban perpajakan yang melekat pada wajib pajak yang dikenakan sanksi tersebut. Menurut Mardiasmo (2016), sanksi perpajakan merupakan alat pencegah (preventif) agar wajib pajak tidak melanggar norma pepajakan. Pelaksanaan sanksi pajak dapat menyebabkan terpenuhinya kewajiban perpajakan oleh wajib pajak, sehingga wajib pajak akan patuh karena mereka memikirkan adanya sanksi berat berupa denda akibat tindakan ilegal dalam usahanya menyelundupkan pajak (Pujiwidodo, 2016).

Kepatuhan wajib pajak masih perlu ditingkatkan dengan mendorong pelaksanaan perpajakan yang transparan, yaitu transparansi pengelolaan pajak di segala bidang, baik bidang administrasi maupun pengelolaan penggunaan dana yang bersumber dari pendapatan pajak tersebut (Siringoringo, 2015). Agar tujuan penerimaan pajak dapat tercapai dengan baik maka perlu ada proses penegakan hukum di bidang perpajakan apalagi dalam menegakkan self assessment system, karena hal tersebut sesuai dengan isi dari pengertian pajak sebagai iuran wajib yang dipaksakan sesuai dengan undang-undang, penegakan hukum berarti memberikan segala sanksi yang tepat dan adil atas pelanggaran yang dilakukan dalam pelaksanaan perpajakan.

\section{SIMPULAN}

\section{Kesimpulan}

1. Berdasarkan hasil uji regresi linear berganda menunjukkan bahwa terdapat pengaruh antara penerapan Good Corporate Governance terhadap kepatuhan wajib pajak 
2. Berdasarkan hasil uji regresi linear berganda menunjukkan bahwa terdapat pengaruh antara penerapan Whistleblowing System terhadap kepatuhan wajib pajak

3. Berdasarkan hasil uji regresi linear berganda menunjukkan bahwa terdapat pengaruh antara Risiko Sanksi Pajak terhadap kepatuhan wajib pajak

\section{Rekomendasi Penelitian Selanjutnya}

Jenis penelitian yang dilakukan adalah penelitian kuantitatif kausalitas karena penelitian ini adalah untuk menguji hipotesis yang telah diajukan yaitu menguji pengaruh variabel-variabel independen terhadap variable dependen sehingga banyak informasi yang tidak mungkin dikaji lebih mendalam untuk menginterpretasikan pengaruh variabel-variabel bebas terhadap variabel terikatnya. Kemudian teknik pengumpulan data yang dilakukan melalui instrumen kuesioner dalam mengukur variabel penelitian. Dalam penelitian ini, responden yang dijadikan sebagai sampel tidak dipilih secara spesifik, untuk itu bagi peneliti berikutnya yang tertarik untuk meneliti variabel-variabel dalam penelitian ini diharapkan dapat memilih respondennya secara tepat, yaitu responden yang memang tidak memperoleh tunjangan pajak penghasilan atau pajak penghasilannya. Pelaksanaan corporate governance menjadi sia-sia, oleh karena itu sangat penting bagi Direktorat Jendral Pajak untuk melakukan sosialisasi yang menyeluruh kepada wajib pajak orang pribadi di kabupaten Sleman, bahwa sekarang ini DJP telah menjalankan corporate governance dalam menjalankan fungsinya, serta harus diterapkan secara maksimal dan berkelanjutan.

\section{IMPLIKASI RISET}

Implikasi teoritis dalam penelitian ini yaitu bahwa perlu adanya kerangka operasional Good Corporate Governance (GCG) untuk menciptakan budaya wajib pajak sehingga akan menciptakan kepatuhan wajib pajak. Sedangkan implikasi praktis dari penelitian ini bertujuan untuk meningkatkan kesadaran pada wajib pajak yang dapat diwujudkan melalui Djp yang harus mempunyai pedoman Good Corporate Governance (GCG) serta menerapkan whistle blowing dan sanksi agar timbul kepatuhan wajib pajak.

\section{UCAPAN TERIMA KASIH}

Kesuksesan dan hasil akhir dari penelitian ini membutuhkan banyak bimbingan dan dampingan dari berbagai pihak dan kami merasa sangat bersyukur bisa menyelesaikan penelitian ini dengan paripurna. Peneliti juga sangat berterima kasih kepada DIKTI atas program hibah penelitian skema pemula yang diberikan serta kepada seluruh pihak yang membantu peneliti menyelesaikan penelitian ini. Segala bantuan yang diterima tidak akan pernah dilupakan oleh peneliti. Penelitian ini tidak dapat diselesaikan tanpa adanya koordinasi dan kerjasama yang baik antara peneliti. Akhir kata, peneliti ingin menyampaikan rasa terima kasih yang mendalam kepada seluruh kolega serta responden yang telah membantu kami.

\section{REFERENSI}

Alijoyo, Antonius dan Subartono Zaini, (2004), Komisaris Independen: Penggerak Praktik GCG di Perusahaan, PT. Indeks, Jakarta

Ghozali, Imam., (2008), Model Persamaan Struktural dengan Program AMOS 16.00, Konsep dan Aplikasi, Semarang, BP UNDIP

Ghozali, Imam, (2013), Structural Equation Modeling Teori, Konsep, dan Aplikasi Dengan Lisrel 8.80 (Edisi 3), Universitas Diponegoro, Semarang

Ilyas. B dan Burton, (2013), Hukum Pajak, Edisi 6, Salemba Empat, Jakarta

La Porta, R. et al, (1998), Corporate Ownership Around the World, Journal of Finance, 471577

Lukviarman, Niki, (2016), Corporate Goernance, Era Adicitra Intermedia, Solo

Mardiasmo, (2016), Perpajakan Edisi terbaru 2016, Andi, Yogyakarta

Pujiwododo, Dwiyatmoko, (2016). Persepsi Sanksi Perpajakan Terhadap Kepatuhan Wajib Pajak 
Orang Pribadi, Jurnal Online Insan Akuntan,

Vol 1, No 1, Juni 2016, $92-116$

Rustiyaningsih, Sri, (2010), Faktor-faktor yang Mempengaruhi Kepatuhan Wajib Pajak.

Jurnal Akuntansi, Fakultas Ekonomi Universitas Katolik Widya Mandala Madiun, Vol 2. No 11

Santoso, Singgih., (2004), SPSS Statistik Parametrik. Penerbit PT. Elex Media Komputindo, Jakarta

Sasmita, Sentya N Arum, (2013), Pengaruh Pemahaman Wajib Pajak, Pelayanan

Fiskus, Kesadaran Wajib Pajak, dan Sanksi Perpajakan terhadap Kepatuhan Wajib Pajak Pemilik Usaha Kecil Menengah dalam
Laporan Kewajiban Perpajakan di Semarang (Studi UMKM di Semarang), Jurnal Akuntansi, Universitas Brawijaya, Vol 7. No 9

Sisingoringo, Whereson, (2015), Pengaruh Good Governance dan Whistleblowing

System Terhadap Kepauhan Wajib Pajak Orang Pribadi Dengan Risiko Sanksi Pajak Sebagai Variabel Moderating (Studi Empiris Terhadap Wajib Pajak Orang Pribadi Di Kota Bekasi), Jurnal Akuntansi, Volume XIX, No. 02, Mei; 207-224

Tricker, B, (2004), Corporate Governance : Principles, Policies and Practices, University Press Oxford, Oxford 